\title{
Heterogeneous Oxidation of Carbonyl Sulfide on Atmospheric Particles and Alumina
}

HONG HE, * J U N F E N G L I U, Y U J I N G M U,
Y U N B O Y U, A N D M I X U E C H E N
State Key Laboratory of Environmental Chemistry and
Ecotoxicology, Research Center for Eco-Environmental
Sciences, Chinese Academy of Sciences, Beijing, 100085, China

Heterogeneous oxidation of carbonyl sulfide (OCS) on atmospheric particles and alumina $\left(\mathrm{Al}_{2} \mathrm{O}_{3}\right)$ was investigated in a closed system and a flowed system using in situ diffuse reflectance infrared Fourier transform spectroscopy (DRIFTS). At room temperature, OCS could be catalytically oxidized on the surface of atmospheric particles and $\mathrm{Al}_{2} \mathrm{O}_{3}$ to form gas-phase $\mathrm{CO}_{2}$ and surface sulfate $\left(\mathrm{SO}_{4}{ }^{2-}\right)$, sulfite $\left(\mathrm{HSO}_{3}{ }^{-}\right)$, and hydrogen carbonate $\left(\mathrm{HCO}_{3}{ }^{-}\right)$species. The real atmospheric particles were characterized using $\mathrm{X}$-ray fluorescence (XRF) and the Brunauer-Emmett-Teller (BET) method. As a simplified model, $\mathrm{Al}_{2} \mathrm{O}_{3}$ was used to study the reaction mechanism of heterogeneous oxidation of OCS. The hydrogen thiocarbonate surface $\left(\mathrm{HSCO}_{2}{ }^{-}\right)$ species, an intermediate formed in the reaction of OCS with surface hydroxyl $(\mathrm{OH})$, could only be observed on the prereduced $\mathrm{Al}_{2} \mathrm{O}_{3}$ sample. The experimental results also indicate that surface oxygen containing species on the atmospheric particle sample and the $\mathrm{Al}_{2} \mathrm{O}_{3}$ sample might be the key reactant for OCS oxidation. A reaction mechanism of heterogeneous oxidation of OCS on $\mathrm{Al}_{2} \mathrm{O}_{3}$ surface is discussed.

\section{Introduction}

Carbonyl sulfide (OCS) is the most abundant atmospheric sulfur gas in the remote troposphere, with an average global mixing ratio of about $500 \pm 50$ pptv (parts per trillion by volume) $(1,2)$. It is relatively inert in the troposphere and its tropospheric lifetime is greater than 1 year $(1-3)$. OCS can be transported into the stratosphere where its photooxidation is considered to be an important source of stratospheric sulfate during volcanically quiescent periods (3-5). Understanding of the global OCS cycle is therefore of considerable importance partially because, so far, the known sources of OCS are not balanced with its sinks (6).

Most studies focus on the homogeneous reaction of OCS with $\mathrm{OH}$ in the gas phase and the consumption of OCS by plants, soil, etc (6). Heterogeneous interactions between gaseous molecules with wet or dry atmospheric particle surfaces have gained considerable interest since they have the potential to significantly alter the process of atmospheric chemistry $(3,7)$. The surface of oxide particles in the atmosphere can adsorb and catalyze reactions of trace gases, and thus change the chemical balance of the atmosphere $(8$, 9). However, very few studies have examined the possibility of heterogeneous reaction and the conversion pathway of

* Corresponding author phone: +86-10-62849123; fax: +86-1062849123; e-mail: honghe@mail.rcees.ac.cn.
OCS on the surface of atmospheric particles. This might be due to the difficulty in studies on the heterogeneous reaction and its mechanisms of trace gases on the complex atmospheric particles.

To understand the mechanism of heterogeneous reaction of OCS on the surface of atmospheric particles, diffuse reflectance infrared Fourier transform spectroscopy (DRIFTS) was used in this study. DRIFTS can be used to obtain the nature of gas-solid surface interactions. In situ DRIFTS is especially useful to explore mechanisms of heterogeneous reaction on solid surfaces by providing information on reactive intermediates formed on the surface. Aluminum is one of the most abundant elements in atmospheric particles. It has been reported that alumina $\left(\mathrm{Al}_{2} \mathrm{O}_{3}\right)$ surface catalyzes the oxidation of either $\mathrm{H}_{2} \mathrm{~S}$ or $\mathrm{CS}_{2}$, and its catalytic property is influenced by pretreatments $(10-12)$. Therefore, it is necessary to investigate the heterogeneous reaction of OCS on the atmospheric particles and study the reaction mechanism on the surface of alumina as a model.

In this experiment, we found that atmospheric particles and $\mathrm{Al}_{2} \mathrm{O}_{3}$ catalyze the heterogeneous oxidation of OCS at room temperature to form gas-phase $\mathrm{CO}_{2}$ and surface sulfate $\left(\mathrm{SO}_{4}{ }^{2-}\right)$, sulfite $\left(\mathrm{HSO}_{3}{ }^{-}\right)$, and hydrogen carbonate $\left(\mathrm{HCO}_{3}{ }^{-}\right)$ species, and we propose a composite reaction mechanism based on the experimental results.

\section{Experimental Section}

2.1. Materials. The atmospheric particle sample (21 g) was collected on the roof of an office building at the Research Center for Eco-Environmental Sciences, Chinese Academy of Science, Beijing. The $\mathrm{Al}_{2} \mathrm{O}_{3}$ sample used in this experiment was supplied by Shandong Aluminum Corporation. Before the DRIFTS measurement, the $\mathrm{Al}_{2} \mathrm{O}_{3}$ sample was pretreated in an in situ infrared cell following one of two basic procedures: the preoxidized $\mathrm{Al}_{2} \mathrm{O}_{3}$ sample obtained by heating in $100 \mathrm{~mL} / \mathrm{min} \mathrm{O}_{2}$ at $573 \mathrm{~K}$ for $2 \mathrm{~h}$; or the prereduced $\mathrm{Al}_{2} \mathrm{O}_{3}$ sample obtained by heating in $100 \mathrm{~mL} / \mathrm{min} \mathrm{H}_{2}$ at 573 $\mathrm{K}$ for $2 \mathrm{~h}$. The preoxidized atmospheric particle sample was pretreated by heating in $100 \mathrm{~mL} / \mathrm{min} \mathrm{O}_{2}$ at $373 \mathrm{~K}$ for $2 \mathrm{~h}$.

The specifications of gases used in this experiment are as follows without further purification: OCS $\left(2 \%, \mathrm{OCS} / \mathrm{N}_{2}\right.$, Scott Specialty Gases Inc.), $\mathrm{O}_{2}$ (99.99\% purity, Beijing AP BEIFEN Gases Inc.), $\mathrm{H}_{2}$ (99.999\% purity, GCD-300B high purity hydrogen generator, China Bchp Analytical Technology Co. Ltd.).

2.2. Techniques of Characterization. $X$-ray Fluorescence. Inorganic elementary analysis was carried out on an Elementary Vario El (Germany) system. X-ray fluorescence (XRF) data were obtained from a Bruker S4 Explorer spectrometer.

BET Experiment. The nitrogen adsorption-desorption isotherms were obtained at $77 \mathrm{~K}$ over the whole range of relative pressures, using a Micromeritics ASAP 2000 automatic equipment. Specific areas were computed from these isotherms by applying the Brunauer-Emmett-Teller (BET) method.

In situ DRIFTS Experiment. In situ DRIFTS spectra were recorded on a Nexus 670 (Thermo Nicolet Instrument Corporation) FT-IR, equipped with an in situ diffuse reflection chamber and a high-sensitivity MCT detector cooled by liquid $\mathrm{N}_{2}$. The sample for the in situ DRIFTS studies was finely ground and placed into a ceramic crucible in the in situ chamber. Mass flow controllers and a sample temperature controller were used to control the reaction conditions. The reference spectrum was measured after the pretreated sample was cooled to $298 \mathrm{~K}$ in a purified $\mathrm{O}_{2}$ or $\mathrm{H}_{2}$ stream. The infrared

VOL. 39, NO. 24, 2005 / ENVIRONMENTAL SCIENCE \& TECHNOLOGY • 9637 

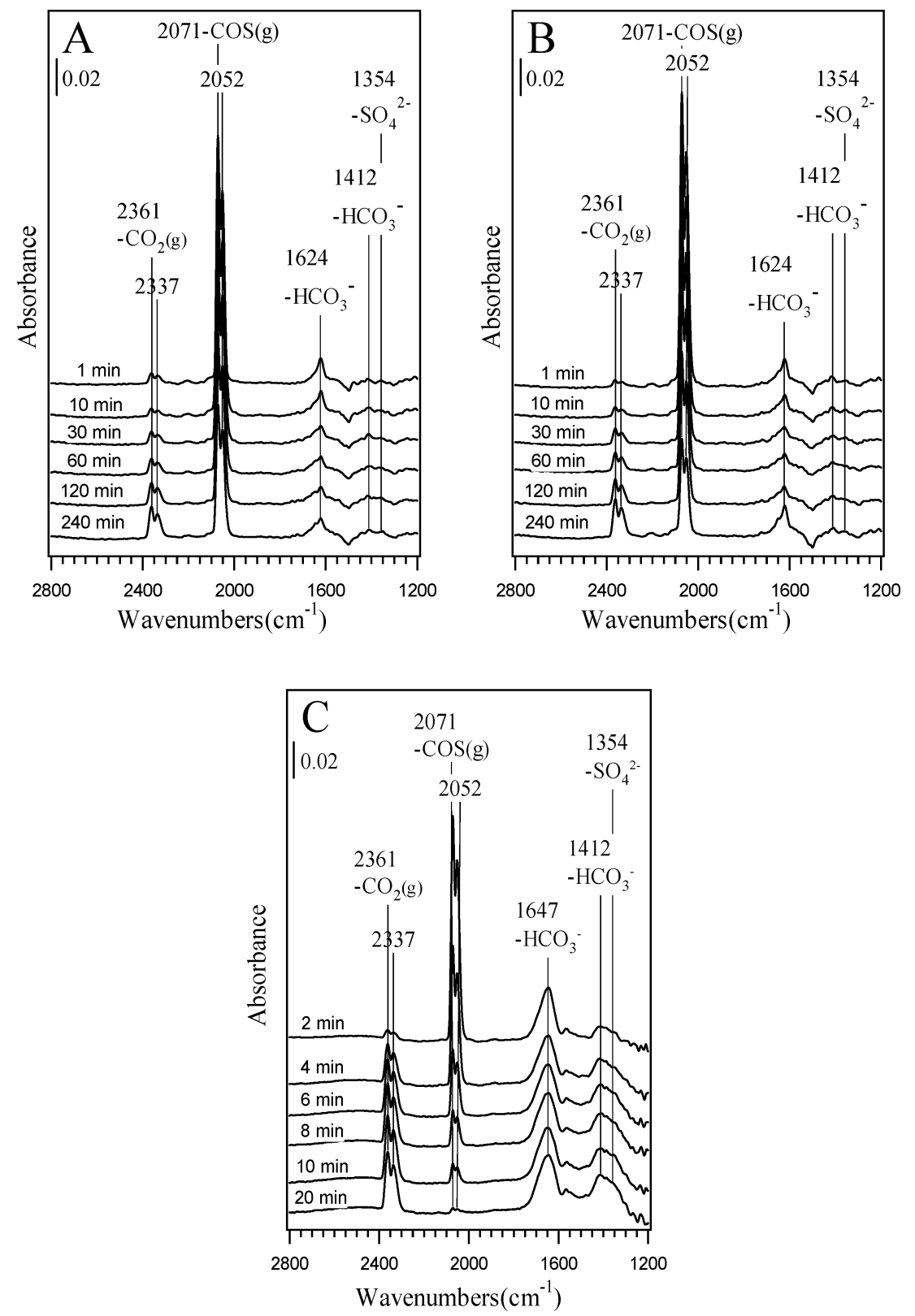

FIGURE 1. Dynamic changes of in situ DRIFTS spectra of the atmospheric particle sample (A), the preoxidized atmospheric particle sample (B), and the preoxidized $\mathrm{Al}_{2} \mathrm{O}_{3}$ sample (C) as a function of time after exposure to $500 \mathrm{ppm} 0 \mathrm{CS}+95 \% \mathrm{O}_{2}$ in a closed system at $298 \mathrm{~K}$.

spectra were collected and analyzed using a data acquisition computer installed with OMNIC 6.0 software (Nicolet Corp.). All spectra reported here were recorded at a resolution of 4 $\mathrm{cm}^{-1}$ for 100 scans.

2.3. Calibration Curve of Gas-Phase OCS Concentration. A series of in situ DRIFTS spectra at steady state of flow system with various concentrations of OCS (40-2000 ppm) were recorded at $298 \mathrm{~K}$. The integrated areas of the absorption peak of gaseous OCS in the range of $1980-2120 \mathrm{~cm}^{-1}$ have a linear correlation with the concentration of OCS $\left(R^{2}>0.99\right)$. On the basis of this result, the concentration of gas-phase OCS can be determined by measuring the in situ DRIFTS spectra peak areas of gaseous OCS.

\section{Results and Discussion}

3.1. Characterizations. X-ray Fluorescence. The inorganic elemental composition of the atmospheric particle sample was determined by XRF measurement. Table 1 exhibits that the major inorganic elements in the atmospheric particle sample are $\mathrm{Si}$ and $\mathrm{Al}$, followed by $\mathrm{Ca}, \mathrm{S}, \mathrm{Fe}$, and $\mathrm{Mg}$.
TABLE 1. Inorganic Element Composition of the Atmospheric Particle Sample

$\begin{array}{lllllllllll}\text { element } & \mathrm{Si} & \mathrm{Al} & \mathrm{Ca} & \mathrm{S} & \mathrm{Fe} & \mathrm{Mg} & \mathrm{K} & \mathrm{Na} & \mathrm{Ti} & \mathbf{P}\end{array}$

$\begin{array}{lllllllllll}\text { percent (\%) } & 38.2 & 12.0 & 7.8 & 6.4 & 5.1 & 4.8 & 1.8 & 1.4 & 0.5 & 0.3\end{array}$

TABLE 2. Specific Area of the Atmospheric Particle Sample and the $\mathrm{Al}_{2} \mathrm{O}_{3}$ Sample

sample atmospheric particles $\quad \mathrm{Al}_{2} \mathrm{O}_{3}$

$\begin{array}{lll}\text { BET area }\left(\mathrm{m}^{2} / \mathrm{g}\right) & 4.8 & 277\end{array}$

BET. BET results are shown in Table 2. The $\mathrm{Al}_{2} \mathrm{O}_{3}$ sample has a much larger surface area than the atmospheric particle sample. Atmospheric particles and $\mathrm{Al}_{2} \mathrm{O}_{3}$ show a striking contrast for studying their catalytic reactivities and reaction mechanisms of OCS oxidation.

3.2. Heterogeneous Reaction of OCS on the Atmospheric Particle Sample, the Preoxidized Atmospheric Particle 


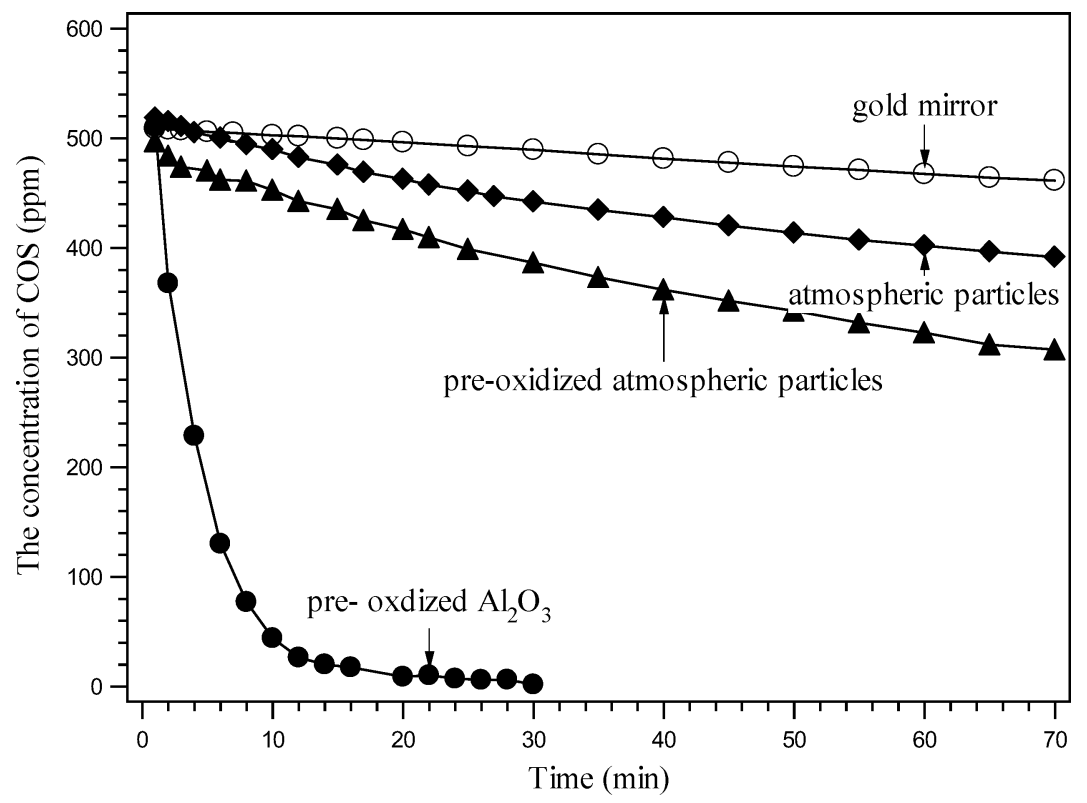

FIGURE 2. Heterogeneous reaction of $500 \mathrm{ppm} \mathrm{OCS}+95 \% \mathrm{O}_{2}$ on the atmospheric particle sample, the preoxidized atmospheric particle sample, the preoxidized $\mathrm{Al}_{2} \mathrm{O}_{3}$ sample, or gold mirror at $298 \mathrm{~K}$ in a closed system.
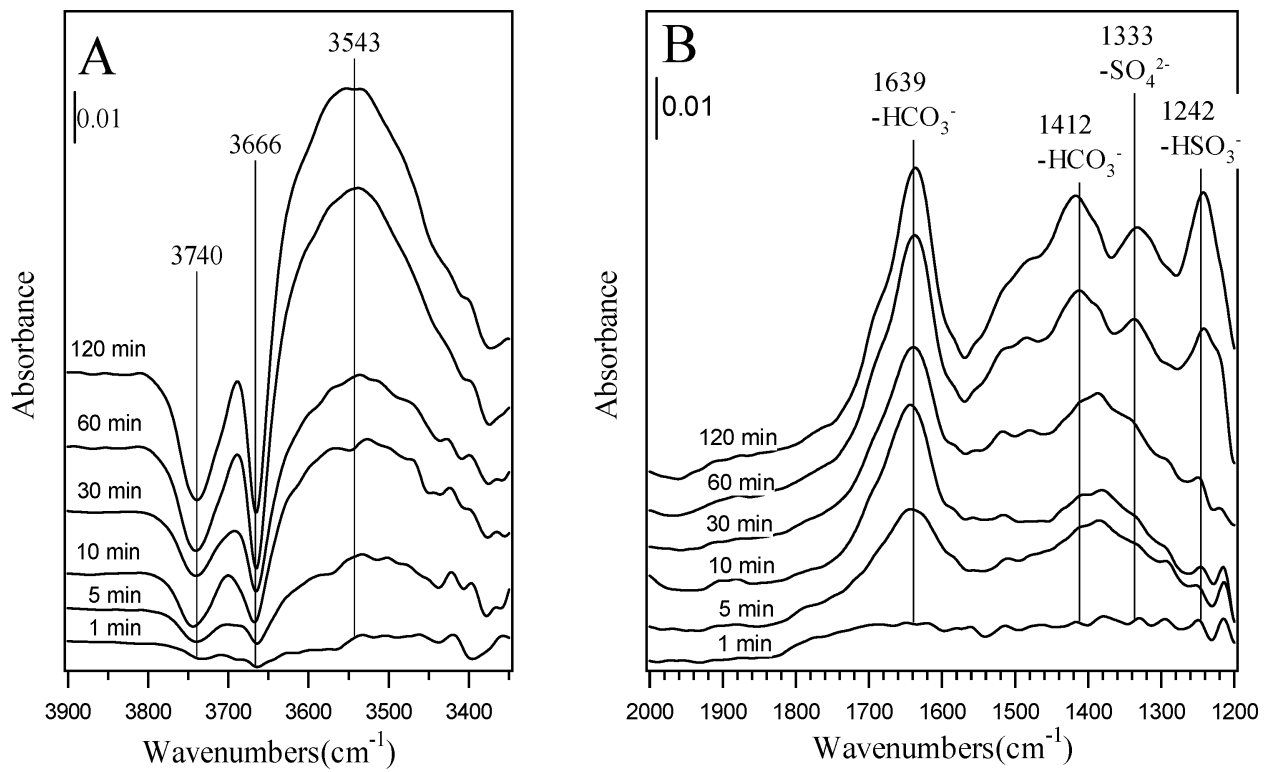

FIGURE 3. Dynamic changes of in situ DRIFTS spectra of the preoxidized $\mathrm{Al}_{2} \mathrm{O}_{3}$ sample as a function of time in a flow of $500 \mathrm{ppm} 0 \mathrm{CS}$ $+95 \% \mathrm{O}_{2}$ at $298 \mathrm{~K}$.

Sample, and the Preoxidized $\mathrm{Al}_{2} \mathrm{O}_{3}$ Sample. The atmospheric particle sample was exposed to a flow of 500 ppm OCS + $95 \% \mathrm{O}_{2}$ at $298 \mathrm{~K}$ for $5 \mathrm{~min}$, and then the inlet and outlet were closed. The in situ DRIFTS spectra on the atmospheric particle sample were recorded as a function of time as shown in Figure 1A. The same experiments were also carried out using the preoxidized atmospheric particle sample and the preoxidized $\mathrm{Al}_{2} \mathrm{O}_{3}$ sample. The results are shown in Figure 1B and C. In Figure 1A, B, and C strong peaks due to gas-phase OCS appeared at 2071 and $2052 \mathrm{~cm}^{-1}(13,14)$. A pair of peaks of gaseous carbon dioxide $\left(\mathrm{CO}_{2}\right)$ were observed at 2337 and $2361 \mathrm{~cm}^{-1}(15-17)$. The bands at 1624 (1647), $1412 \mathrm{~cm}^{-1}$ are due to surface $\mathrm{HCO}_{3}{ }^{-}$species $(13,15-17)$, and the band at $1354 \mathrm{~cm}^{-1}$ is assigned to surface $\mathrm{SO}_{4}{ }^{2-}$ species $(18-22)$. It is also found that the peaks for gas-phase $\mathrm{CO}_{2}$, surface $\mathrm{HCO}_{3}{ }^{-}$, and $\mathrm{SO}_{4}{ }^{2-}$ species increase in intensity with time, while the peaks for gaseous OCS diminish, suggesting that OCS in $\mathrm{O}_{2}$ can be converted into $\mathrm{CO}_{2}$, surface $\mathrm{HCO}_{3}{ }^{-}$, and $\mathrm{SO}_{4}{ }^{2-}$ species on the samples of atmospheric particles, the preoxidized atmospheric particles, and the preoxidized $\mathrm{Al}_{2} \mathrm{O}_{3}$ at $298 \mathrm{~K}$.

The gas-phase OCS concentration shown in Figure 2 was determined by comparing OCS absorbance peak area with the calibration curve of gas-phase OCS concentration. The control experiment with a gold mirror indicated that the system may consume a small quantity of OCS through the absorption or the heterogeneous reaction catalyzed by the surface of the system. The concentration of gaseous OCS decreases moderately with the atmospheric particle sample and the preoxidized atmospheric particle sample, whereas it decreases rapidly with the preoxidized $\mathrm{Al}_{2} \mathrm{O}_{3}$ sample. Since the final products over the atmospheric particle sample and the preoxidized $\mathrm{Al}_{2} \mathrm{O}_{3}$ sample are completely the same, this reaction rate is mostly determined by the surface area and catalytic activity. The preoxidized $\mathrm{Al}_{2} \mathrm{O}_{3}$ sample apparently has a larger surface area and higher catalytic activity than the atmospheric particle sample. Therefore, as a simplified 

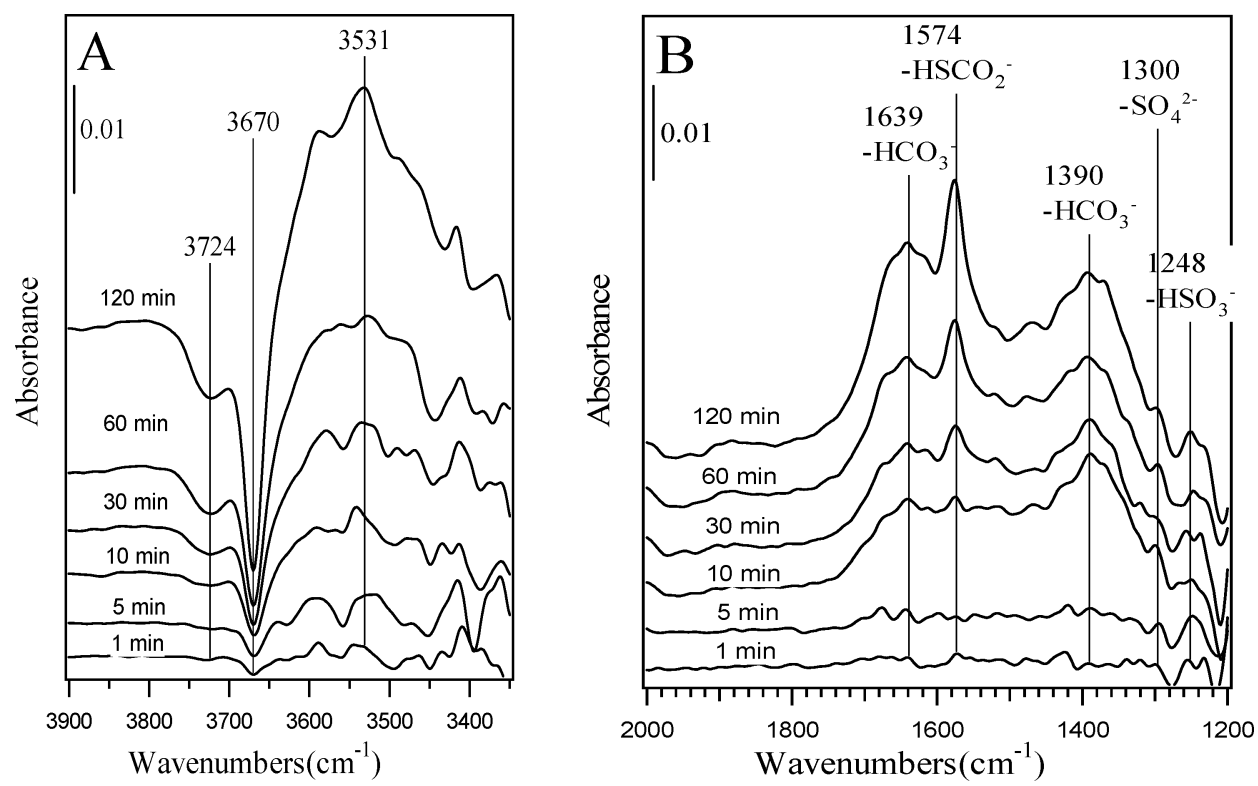

FIGURE 4. Dynamic changes of in situ DRIFTS spectra of the prereduced $\mathrm{Al}_{2} \mathrm{O}_{3}$ sample as a function of time in a flow of $500 \mathrm{ppm} 0 \mathrm{CS}$ $+95 \% \mathrm{H}_{2}$ at $298 \mathrm{~K}$.

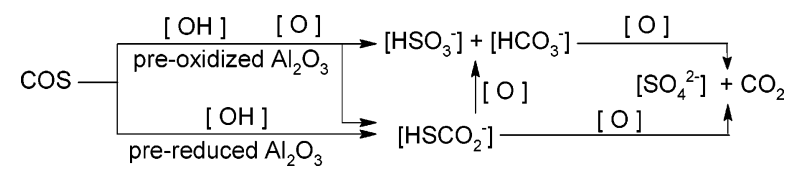

FIGURE 5. Mechanism of heterogeneous oxidation of OCS on the pretreated $\mathrm{Al}_{2} \mathrm{O}_{3}$ sample.

model, the reaction mechanism on the surface of $\mathrm{Al}_{2} \mathrm{O}_{3}$ was examined.

3.3. Dynamic State in Situ DRIFTS Study of OCS $+95 \%$ $\mathrm{O}_{2}$ on the Preoxidized $\mathrm{Al}_{2} \mathrm{O}_{3}$ Sample in a Flow System. The preoxidized $\mathrm{Al}_{2} \mathrm{O}_{3}$ sample was exposed to a flow of $500 \mathrm{ppm}$ OCS $+95 \% \mathrm{O}_{2}$ at $298 \mathrm{~K}$. Figure 3 shows the in situ DRIFTS spectra of the preoxidized $\mathrm{Al}_{2} \mathrm{O}_{3}$ sample as a function of time in the system. It is evident that the intensities of the negative peaks at 3740 and $3666 \mathrm{~cm}^{-1}$ and the positive broad peak at $3543 \mathrm{~cm}^{-1}$ increased drastically with time (Figure 3A). In the model proposed by Peri $(23,24)$, these bands were attributed to the vibrations of surface hydroxyl $(\mathrm{OH})$ species. The band at $3543 \mathrm{~cm}^{-1}$ was assigned to the hydrogen binding of OCS or $\mathrm{CO}_{2}$ or sulfur dioxide $\left(\mathrm{SO}_{2}\right)(19,22)$. This result implies that the surface $\mathrm{OH}$ might be the reaction active site for OCS. Additionally, the peaks due to the adsorptions of surface $\mathrm{SO}_{4}{ }^{2-}\left(1333 \mathrm{~cm}^{-1}\right), \mathrm{HCO}_{3}{ }^{-}$(1639 and $\left.1412 \mathrm{~cm}^{-1}\right)$, and $\mathrm{HSO}_{3}{ }^{-}$ species $\left(1242 \mathrm{~cm}^{-1}\right)$ were observed $(25,26)$, and the intensities of these peaks increased with time (Figure 3B).

To confirm our assignment about the surface $\mathrm{SO}_{4}{ }^{2-}$ species, $1.0 \mathrm{~g}$ of preoxidized $\mathrm{Al}_{2} \mathrm{O}_{3}$ sample after exposure to a flow of $500 \mathrm{ppm} \mathrm{OCS}+95 \% \mathrm{O}_{2}$ at $298 \mathrm{~K}$ for $2 \mathrm{~h}$ was analyzed by ion chromatography (DIONEX, CA); $2.43 \mathrm{mg} / \mathrm{L} \mathrm{SO}_{4}{ }^{2-}$ can be detected (sample stirred with $100 \mathrm{~mL}$ deionized water, and then filtered through a $0.45-\mu \mathrm{m}$ filter). This result confirms the formation of the surface $\mathrm{SO}_{4}{ }^{2-}$ species on the preoxidized $\mathrm{Al}_{2} \mathrm{O}_{3}$ sample.

3.4. Dynamic State in Situ DRIFTS Study of OCS $+\mathbf{9 5 \%}$ $\mathrm{H}_{2}$ on the Prereduced $\mathrm{Al}_{2} \mathrm{O}_{3}$ Sample in a Flow System. The above results confirm that OCS in $\mathrm{O}_{2}$ can be heterogeneously
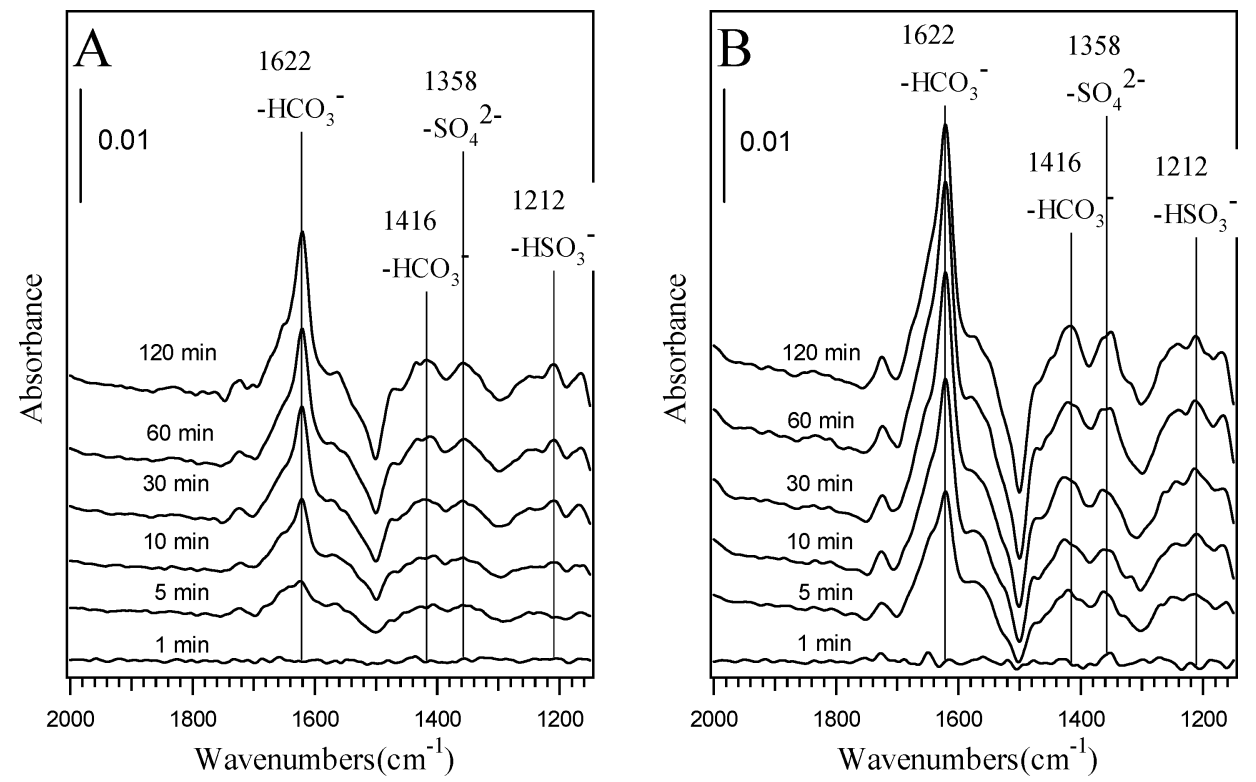

FIGURE 6. Dynamic changes of in situ DRIFTS spectra of the atmospheric particle sample $(A)$ and the preoxidized atmospheric particle sample (B) as a function of time in a flow of $500 \mathrm{ppm} \mathrm{0CS}+95 \% \mathrm{O}_{2}$ at $298 \mathrm{~K}$. 
oxidized into $\mathrm{CO}_{2}$, surface $\mathrm{HCO}_{3}{ }^{-}$, and $\mathrm{SO}_{4}{ }^{2-}$ species on the preoxidized $\mathrm{Al}_{2} \mathrm{O}_{3}$ sample. However, some other intermediates, key to the understanding of the mechanism of OCS conversion, were not identified in this rapid reaction. Considering that the $\mathrm{H}_{2}$ pretreatment of $\mathrm{Al}_{2} \mathrm{O}_{3}$ is expected to weaken its catalytic activity for OCS oxidation, a further experiment was performed on the prereduced $\mathrm{Al}_{2} \mathrm{O}_{3}$ sample to characterize these intermediates.

Figure 4 shows the in situ DRIFTS spectra of the prereduced $\mathrm{Al}_{2} \mathrm{O}_{3}$ sample in a flow of 500 ppm OCS $+95 \%$ $\mathrm{H}_{2}$ at $298 \mathrm{~K}$. Compared with Figure 3, the 1639 and $1390 \mathrm{~cm}^{-1}$ bands indicated similar evidence for surface $\mathrm{HCO}_{3}{ }^{-}$species, but the bands associated with the surface $\mathrm{SO}_{4}{ }^{2-}$ species at $1300 \mathrm{~cm}^{-1}$ and $\mathrm{HSO}_{3}{ }^{-}$species at $1248 \mathrm{~cm}^{-1}$ were significantly weak (Figure 4B). In contrast, a new peak at $1574 \mathrm{~cm}^{-1}$, which was assigned to $\mathrm{HSCO}_{2}{ }^{-}(13,27)$, was observed. It is apparent that the $\mathrm{Al}_{2} \mathrm{O}_{3}$ pretreated by $\mathrm{H}_{2}$ slows down COS oxidation and enables the observation of a reaction intermediate. In the region of hydroxyl groups, a drastic increase in the intensity of negative peak attributed to the vibration of surface $\mathrm{OH}$ species at $3670 \mathrm{~cm}^{-1}$ was observed (Figure 4A). This strongly suggests that the formation of surface $\mathrm{HSCO}_{2}{ }^{-}$ species derives from the reaction between surface $\mathrm{OH}$ species and OCS. Comparing with Figure 3, pretreatment of $\mathrm{Al}_{2} \mathrm{O}_{3}$ using $\mathrm{H}_{2}$ only reduces the formation of surface $\mathrm{SO}_{4}{ }^{2-}$ and $\mathrm{HSO}_{3}{ }^{-}$species, but cannot block the formation of surface $\mathrm{HSCO}_{2}{ }^{-}$and $\mathrm{HCO}_{3}{ }^{-}$species.

On the basis of the above results, we propose a mechanism of the heterogeneous oxidation of OCS on $\mathrm{Al}_{2} \mathrm{O}_{3}$ as shown in Figure 5.

OCS can be oxidized into $\mathrm{CO}_{2}$, surface $\mathrm{HSO}_{3}{ }^{-}, \mathrm{HCO}_{3}{ }^{-}$, and $\mathrm{SO}_{4}{ }^{2-}$ species on the preoxidized $\mathrm{Al}_{2} \mathrm{O}_{3}$ sample at room temperature. When active oxygen containing surface species was consumed, $\mathrm{O}_{2}$ in the gas phase can supplement it so that the oxidation reaction can continue until the surface is covered by $\mathrm{SO}_{4}{ }^{2-}$ species. While the prereduced $\mathrm{Al}_{2} \mathrm{O}_{3}$ sample is exposed to OCS $+\mathrm{H}_{2}$, the reaction between surface $\mathrm{OH}$ and OCS occurs and further oxidation of OCS is slowed. As a result, surface $\mathrm{HSCO}_{2}{ }^{-}$species became a dominant surface species under the reductive condition.

3.5. Dynamic State in Situ DRIFTS Study of OCS $+\mathbf{9 5 \%}$ $\mathrm{O}_{2}$ on the Atmospheric Particle Sample and the Preoxidized Atmospheric Particle Sample in a Flow System. Figure 6 shows the dynamic changes of the in situ DRIFTS spectra of the atmospheric particle sample (Figure 6A) and the preoxidized atmospheric particle sample (Figure 6B) exposed to a flow of $500 \mathrm{ppm}$ OCS $+95 \% \mathrm{O}_{2}$ at $298 \mathrm{~K}$ as a function of time. In both Figure $6 \mathrm{~A}$ and $\mathrm{B}$, the surface $\mathrm{SO}_{4}{ }^{2-}$ species $\left(1358 \mathrm{~cm}^{-1}\right), \mathrm{HCO}_{3}{ }^{-}$species (1622 and $\left.1416 \mathrm{~cm}^{-1}\right)$, and $\mathrm{HSO}_{3}{ }^{-}$ species $\left(1212 \mathrm{~cm}^{-1}\right)$ were observed, and the intensity of these peaks increased with time. These results confirm that OCS can also be oxidized into $\mathrm{CO}_{2}$, surface $\mathrm{HSO}_{3}{ }^{-}, \mathrm{HCO}_{3}{ }^{-}$, and $\mathrm{SO}_{4}{ }^{2-}$ species on the atmospheric particle sample in a flow system at room temperature. Since the real atmospheric particle sample has relatively high surface area $\left(4.8 \mathrm{~m}^{2} / \mathrm{g}\right)$, its influence on the conversion of OCS in atmosphere is not neglectable. It should be noted that the preoxidized atmospheric particle sample shows a higher reactivity for its rich oxygen containing surface species. These results correspond with the proposed mechanism of the heterogeneous oxidation of OCS very well.

This study reveals that OCS can be catalytically oxidized on the real atmospheric particles and $\mathrm{Al}_{2} \mathrm{O}_{3}$ to produce gasphase $\mathrm{CO}_{2}$, surface $\mathrm{HSO}_{3}{ }^{-}, \mathrm{HCO}_{3}{ }^{-}$, and $\mathrm{SO}_{4}{ }^{2-}$ species at room temperature. The pretreatment of $\mathrm{Al}_{2} \mathrm{O}_{3}$ obviously influenced the mechanism of OCS heterogeneous oxidation. The hydrogen thiocarbonate surface $\left(\mathrm{HSCO}_{2}{ }^{-}\right)$species, an intermediate formed in the reaction of OCS with surface hydroxyl $(\mathrm{OH})$, can only be observed on the prereduced $\mathrm{Al}_{2} \mathrm{O}_{3}$ sample. The order of catalytic reactivity for heterogeneous oxidation of OCS is the preoxidized $\mathrm{Al}_{2} \mathrm{O}_{3}$ sample $\gg$ the preoxidized atmospheric particle sample $>$ the atmospheric particle sample.

\section{Acknowledgments}

This work has been supported by the National Natural Science Foundation of China (40275038).

\section{Literature Cited}

(1) Torres, A. L.; Maroulis, P. J.; Goldberg, A. B.; Bandy, A. R. Atmospheric OCS measurements on project Gametag. J. Geophys. Res. 1980, 85, 7357-7360.

(2) Khalil, M. A. K.; Rasmussen, R. A. Global sources, lifetimes and mass balances of carbonyl sulfide (OCS) and carbon disulfide $\left(\mathrm{CS}_{2}\right)$ in the earth's atmosphere. Atmos. Environ. 1984, 18, 18051813.

(3) Andreae, M. O.; Crutzen, P. J. Atmospheric aerosols: biogeochemical sources and role in atmospheric chemistry. Science 1997, 276, 1052-1058.

(4) Crutzen, P. J. The possible importance of CSO for the sulfate layer of the stratosphere. Geophys. Res. Lett. 1976, 3, 73-76.

(5) Turco, R. P.; Whitten, R. C.; Toon, O. B.; Pollack, J. B.; Hamill, P. OCS, stratospheric aerosols and climate. Nature 1980, 283, 283-285.

(6) Watts, S. F. The mass budgets of carbonyl sulfide, dimethyl sulfide, carbon disulfide and hydrogen sulfide. Atmos. Environ. 2000, 34, 761-779.

(7) Baltensperger, U.; Ammann, M.; Kalberer, M.; Gäggeler, H. W. Chemical reactions on aerosol particle surfaces: concept and methods. J. Aerosol Sci. 1996, 27, S651-S652.

(8) Ravishankara, A. R. Heterogeneous and multiphase chemistry in the troposphere. Science 1997, 276, 1058-1065.

(9) Al-Abadleh, H. A.; Grassian, V. H. Oxide surfaces as environmental interfaces. Surf. Sci. Rep. 2003, 52, 63-161.

(10) Liu, C. L.; Chuang, T. T.; Dalla Lana, I. G. The oxidizing properties of $\gamma$-alumina: Infrared studies of the adsorption of $\mathrm{H}_{2} \mathrm{~S}$ and $\mathrm{CS}_{2}$. J. Catal. 1972, 26, 474-476.

(11) Datta, A.; Cavell, R. G. Claus catalysis. 2. An FTIR study of the adsorption of $\mathrm{H}_{2} \mathrm{~S}$ on the alumina catalyst. J. Phys. Chem. 1985 , $89,450-454$

(12) Wang, L.; Zhang, F.; Chen, J. M. Carbonyl sulfide derived from catalytic oxidation of carbon disulfide over atmospheric particles. Environ. Sci. Technol. 2001, 35, 2543-2547.

(13) Lavalley, J. C.; Travert, J.; Chevreau, T.; Lamotte, J.; Saur, O. Infrared study of coadsorption of $\mathrm{H}_{2} \mathrm{~S}$ and $\mathrm{CO}_{2}$ on $\gamma$-alumina. J. Chem. Soc., Chem. Commun. 1979, 4, 146-148.

(14) Dohrmann, J.; Glebov, A.; Toennies, J. P.; Weiss, H. Structure and dynamics of a monolayer OCS on $\mathrm{NaCl}(001)$ : a combined FTIRS, HAS and LEED study. Surf. Sci. 1996, 368, 118-125.

(15) Amenomiya, Y.; Morikawa, Y.; Pleizier, G. Infrared spectroscopy of $\mathrm{C}^{18} \mathrm{O}_{2}$ on alumina. J. Catal. 1977, 46, 431-433.

(16) Morterra, C.; Zecchina, A.; Coluccia, S.; Chiorino, A. IR spectroscopic study of $\mathrm{CO}_{2}$ adsorption onto $\eta-\mathrm{Al}_{2} \mathrm{O}_{3}$. J. Chem. Soc., Faraday Trans. $\$ 1977,73,1544-1560$.

(17) Nemeth, L.; Gati, G.; Gervasini, A.; Auroux, A.; Mink, G.; Pap I. S.; Szekely, T. Kinetic study of the carbonyl sulphide synthesis from carbon dioxide and carbon disulphide on alumina catalysts. Appl. Catal. 1990, 64, 143-159.

(18) Saur, O.; Bensitel, M.; Mohammed Saad, A. B.; Lavalley, J. C.; Tripp, C. P.; Morrow, B. A. The structure and stability of sulfated alumina and titania. J. Catal. 1986, 99, 104-110.

(19) Lavalley, J. C. Infrared spectrometric studies of the surface basicity of metal oxides and zeolites using adsorbed probe molecules. Catal. Today 1996, 27, 377-401.

(20) Yang, R. T.; Li, W. B.; Chen, N. Reversible chemisorption of nitric oxide in the presence of oxygen on titania and titania modified with surface sulfate. Appl. Catal., A 1998, 169, 215225 .

(21) Meunier, F. C.; Ross, J. R. H. Effect of ex situ treatments with $\mathrm{SO}_{2}$ on the activity of a low loading silver-alumina catalyst for the selective reduction of $\mathrm{NO}$ and $\mathrm{NO}_{2}$ by propene. Appl. Catal., B 2000, 24, 23-32.

(22) Sahibed-Dine, A.; Aboulayt, A.; Bensitel, M.; Mohammed Saad, A. B.; Daturi, M.; Lavalley, J. C. IR study of $\mathrm{CS}_{2}$ adsorption on metal oxides: relation with their surface oxygen basicity and mobility. J. Mol. Catal. A: Chem. 2000, 162, 125-134.

(23) Peri, J. B.; Hannan, R. B. Surface hydroxyl groups on $\gamma$-Alumina. J. Phys. Chem. 1960, 64, 1526-1530. 
(24) Peri, J. B. A model for the surface of $\gamma$-alumina. J. Phys. Chem. 1965, 69, 220-230.

(25) Laniecki, M.; Ziólek, M.; Karge, H. G. Effect of water on the formation of $\mathrm{HSO}_{3}{ }^{-}$ions upon $\mathrm{SO}_{2}$ adsorption onto Faujasitetype zeolites. J. Phys. Chem. 1987, 91, 4-6.

(26) Mitchell, M. B.; Sheinker, V. N.; White, M. G. Adsorption and reaction of sulfur dioxide on alumina and sodium-impregnated alumina. J. Phys. Chem. 1996, 100, 7550-7557.
(27) Hoggan, P. E.; Aboulayt, A.; Pieplu, A.; Nortier, P.; Lavalley, J. C. Mechanism of COS hydrolysis on alumina. J. Catal. 1994, $149,300-306$

Received for review July 22, 2004. Revised manuscript received September 27, 2005. Accepted October 12, 2005.

ES048865Q 